\title{
Dehydrogenase Patterns in the Taxonomy of Bacteroides
}

\author{
By H. N. SHAH ${ }^{1 *}$ AND R. A. D. WILLIAMS ${ }^{2}$ \\ ${ }^{1}$ Department of Oral Microbiology and ${ }^{2}$ Department of Biochemistry, London Hospital Medical \\ College, Turner Street, London E1 2AD, U.K.
}

(Received 4 January 1982; revised 23 April 1982)

The malate dehydrogenase (MDH) electrophoretic mobilities of 128 strains of bacteroides belonging to 17 species, including three subspecies of Bacteroides melaninogenicus and two subspecies of Bacteroides ruminicola, were examined. Amongst the pigmented bacteroides, the migration of this enzyme correlated well with recognized taxa, and only one strain, VPI 9085 was clearly different. Other species such as $B$. oralis, $B$. buccalis, $B$. denticola, $B$. pentosaceus, $B$. bivius, $B$. disiens and $B$. ruminicola were delineated by the combined use of MDH and glutamate dehydrogenase. Forty-three strains belonging to the ' $B$. fragilis group' differed from the above species in possessing glucose-6-phosphate dehydrogenase and 6-phosphogluconate dehydrogenase, and reference strains as well as fresh isolates were assigned to the correct species by the mobility pattern of these two enzymes.

Other properties of $\mathrm{MDH}$ such as the $\mathrm{pH}$ optima for the oxidation of malate or the reduction of oxaloacetate were of limited taxonomic value. However, the alkaline stability of this enzyme at $\mathrm{pH} 9,10$ and 11 clearly differentiates the saccharolytic from the non-saccharolytic species of pigmented bacteroides with the latter showing highly stable enzymes with a half life greater than $50 \mathrm{~min}$.

\section{INTRODUCTION}

Many physiological tests used in bacteriology depend on the presence of particular enzymes. The measurement of enzyme activities within cells has also been used in taxonomy (De Ley, 1962, 1968; Bascombe, 1980) and the presence of key enzymes, and metabolic pathways dependent upon them is fundamental to the production of distinctive patterns of metabolic endproducts (Sokatch, 1969). If an enzyme is present within all strains of a group of bacteria then its activity is of no taxonomic value (Norris, 1968), but its molecular properties can be detectably different in various taxa. One easily detectable difference is electrophoretic mobility (Shaw, 1965), but other properties such as molecular weight and coenzyme specificity may also be used (Weitzman, 1980). We have reported differences in malate dehydrogenase (MDH) mobilities between the three formerly recognized subspecies of Bacteroides melaninogenicus (Williams et $a l ., 1975$ ). Malate dehydrogenase is not found in fusobacteria but its presence was confirmed in a larger study of the black-pigmented bacteroides (Shah et al., 1976), although heterogeneity of both MDH mobility and DNA base composition was evident. The only available reference strain of B. melaninogenicus subsp. melaninogenicus used initially (VPI 9085) was later shown to be quite different to other strains of this subspecies (Shah et al., 1976), and was listed as a species incertae sedis (Shah, 1981). The value of MDH mobility was supported by the correspondence between enzyme mobility and DNA base composition (Shah et al., 1976) which revealed two distinct taxa for which new species names have been proposed (Coykendall et al., 1980; van Steenbergen et al., 1981). This paper describes the mobility of MDH in a wider group of pigmented bacteroides strains, and the stability and $\mathrm{pH}$ optima of this enzyme, together with the electrophoretic patterns of other enzymes in both pigmented and non-pigmented bacteroides. 


\section{METHODS}

Bacterial strains. The 128 strains of Bacteroides, mostly of human oral origin, used are listed in Table 1 . Growth of cultures and preparation of cell-free extracts. Strains were grown in liquid media as described previously (Shah et al., 1976). For electrophoresis of enzymes cells were grown anaerobically under $10 \%$ carbon dioxide, $20 \%$ hydrogen in nitrogen for $3 \mathrm{~d}$ at $37^{\circ} \mathrm{C}$ on plates containing defibrinated horse blood (Wellcome), $5 \%$ (w/v) and Blood Agar Base no. 2 (Oxoid), 4\% (w/v).

Table 1. Strains used and their sources

Strain no.

Bacteroides asaccharolyticus

VPI 4198

VPI 4199

NCTC 9337

B 536

B 537

B 477

Bacteroides bivius

VPI 6822

VPI 6318

'Bacteroides bivius-like'

5540

7880

Bacteroides disiens

VPI 7852

VPI 8057

Bacteroides distasonis ATCC 8503

three clinical isolates

Bacteroides eggerthii

NCTC 11155

Bacteroides fragilis

NCTC 8560

NCTC 9343

13 clinical isolates

Bacteroides gingivalis

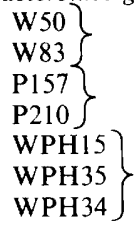

Bacteroides melaninogenicus subsp. intermedius

NCTC 9336

NCTC 9338

B9

B18

B22

B23

N275-70A

$3 \mathrm{~b}$

D13a-fl $\}$

G11a-d2 $\}$

JP1

2845

2846

2849

P209)

P156 $\}$

Source

(received from)*

Site of isolation

VPI

V. L. Sutter

NCTC

V. L. Sutter

V. L. Sutter

V. L. Sutter

VPI

VPI

E. M. Barnes

E. M. Barnes

VPI

VPI

ATCC

London Hospital

B. I. Duerden

NCTC

NCTC

London Hospital

H. Werner

P. Kho

W. P. Holbrook

NCTC

NCTC

T. Hofstad

D. W. Lambe

W. Loesche

J. Carlsson

M. M. Garcia

V. L. Sutter

V. L. Sutter

V. L. Sutter

P. Kho
Empyema

Human faeces

Infected haemorrhoids

Human faeces

Human leg lesion

Human faeces

Endometrium

Vaginal swabs

Clinical specimen

Clinical specimen

Draining stomach infusion

Bartholin abscess

Faeces

NK

Appendectomy

Appendix abscess

Clinical specimen

Periodontal plaque

Dental plaque

Vincent's gingivitis

Empyema

Gingival mucosa

Oral specimen

Dental root canal

Cattle horn abscess

Post gastrectomy wound

Lung aspirate

Trans-tracheal aspirate

Peridontal plaque 
Table 1 (continued)

Source

Strain no. (received from)*

Own isolates

Dental plaque

M. M. Garcia

N334-71H

$23 \mathrm{~K} 9$

S2

S5

S13

$\mathrm{S} 14$

S18

$\mathrm{S} 21$

$\mathrm{S} 22$

S25

S26

Bacteroides oralis

ACTC 33269

'Bacteroides oralis-like'

VPI $8096 \mathrm{D}\}$ (B. buccalis)

$\left.\begin{array}{l}1210 \\ 1221\end{array}\right\}$ (B. denticola)

Bacteroides ovatus

ATCC 8483

2 clinical isolates

Bacteroides ruminicola

subsp. brevis

GA33

$118 \mathrm{~B}\}$

B5

Bacteroides ruminicola

subsp. ruminicola

R1

R2

R5
Site of isolation
Rumen
M. Lev

E. Cato

E. Cato

V. L. Sutter

V. L. Sutter

V. L. Sutter

V. L. Sutter

D. W. Lambe

D. W. Lambe

C. B. Sabiston

Cattle horn abscess

Rumen contents

Gingival crevice

Human sputum

Faecal fluid-ruptured bowel

Trans-tracheal aspirate

Trans-tracheal aspirate

Peritoneal fluid

NK

Oral specimen

Peridontal abscess

Own isolate

Dental plaque

VPI

VPI

Own isolate

S. S. Socransky

London Hospital

NK

M. J. Latham Rumen 
Table 1 (continued)

Strain no.

$\left.\begin{array}{l}\text { Bacteroides ruminicola-like' } \\ \text { NP333 } \\ \text { WPH61 } \\ \mathrm{J} 1\end{array}\right\}$ (B. pentosaceus)
Bacteroides splanchnicus
NCTC 10826
Bacteroides thetaiotaomicron
NCTC 10582
W910
10 clinical isolates
Bacteroides vulgatus
WBM 137
6 clinical isolates

Source

(received from)*

Own isolate

W. P. Holbrook

W. J. Loesche

B. I. Duerden

NCTC

H. Werner

London Hospital

H. Werner

London Hospital

Site of isolation

Dental plaque
Dental plaque
Dental plaque

NK

Faeces

NK

NK

NK, Not known.

* VPI, Virginia Polytechnic Institute; NCTC, National Collection of Type Cultures; ATCC, American Type Culture Collection.

Cells were harvested from liquid culture (Shah et al., 1976) or from blood agar plates (three per strain) by suspending the cells in 0.1 M-HEPES buffer pH 8.0 (BDH). The cell suspension was shaken with Ballotini beads (Grade 12, Jencons Ltd.) for $15 \mathrm{~min}$ in a Mickle Tissue disintegrator (Mickle Engineering Ltd, Gomshall, Surrey) at $4{ }^{\circ} \mathrm{C}$. Beads, cell debris and unbroken cells were removed by centrifugation at $37000 \mathrm{~g}$ for $15 \mathrm{~min}$ and the supernatant, containing $20-30 \mathrm{mg}$ protein $\mathrm{ml}^{-1}$, was used for studies of the enzymes.

Electrophoresis and staining of dehydrogenases. Cellogel strips $5.7 \times 14 \mathrm{~cm}$ (Reeve Angel Scientific Ltd) were soaked in $0.04 \mathrm{M}$-barbitone-acetate buffer pH $8.630 \mathrm{~min}$ before use. Cell-free extracts were loaded $(1.2 \mu \mathrm{l})$ at the origin line and electrophoresed for $1 \mathrm{~h}$ at 10 volts per $\mathrm{cm}$ length of the gel upon a supporting block of the LKB Multiphor cooled by water at $10^{\circ} \mathrm{C}$. Enzymes were stained as follows : malate dehydrogenase (MDH) according to Williams et al. (1975); glutamate dehydrogenase (GDH) by the method for MDH except that glutamate was substituted for malate; glucose-6-phosphate dehydrogenase (G6PDH), following the procedure of Williams \& Bowden (1968); and 6-phosphogluconate dehydrogenase (6PGDH) by the method for G6PD except that 6phosphogluconate was substituted for glucose-6-phosphate. For MDH and GDH enzymes NAD was used whereas NADP and NAD were used for G6PD and 6PGD.

Measurement of enzyme activity. All enzyme assays were carried out at $25^{\circ} \mathrm{C}$ in a Gilford model 240 spectrophotometer. Bacterial extracts prepared as above (for electrophoresis) were assayed for enzyme activity by following the formation of the reduced pyridine nucleotide at $340 \mathrm{~nm}$ according to Reeves et al. (1971). Reactions were carried out in $3 \mathrm{ml}$ volumes at pH 7.5 in $0.1 \mathrm{M}$-HEPES buffer and contained $0.49 \mathrm{~mm}-\mathrm{NAD}$. Substrate concentrations were $5 \mathrm{~mm}$-L-malate, $3.5 \mathrm{~mm}$-glutamate, $2.2 \mathrm{~mm}$-glucose 6-phosphate or $1.8 \mathrm{~mm}$-6-phosphogluconate.

Determination of $\mathrm{pH}$ optimum. The $\mathrm{pH}$ optimum for the oxidation of $\mathrm{L}$-malate was determined by the above procedure. The reduction of oxaloacetate to malate was assayed by following the disappearance of NADH at $340 \mathrm{~nm}$. The reaction mixtures contained $0 \cdot 1 \mathrm{M}$ buffer, $0 \cdot 24 \mathrm{mM}-\mathrm{NADH}$ and $2.5 \mathrm{~mm}$-oxaloacetate. The buffers used were MES, MOPS, HEPES, CHES, CAPS and Tricine (BDH).

Determination of the half inactivation times of malate dehydrogenase in alkaline buffers. Cell-free extracts were incubated separately in buffers at $\mathrm{pH} 9,10$ or 11 for up to $50 \mathrm{~min}$ in a $37^{\circ} \mathrm{C}$ waterbath. Samples $(0 \cdot 1 \mathrm{ml})$ were removed at timed intervals and assayed for MDH activity (reduction of oxaloacetate) as described above. The percentage enzyme activity relative to the initial reaction of extracts not treated with alkaline buffers was calculated. The time taken for a $50 \%$ loss of activity $\left(t_{0.5}\right.$, the half inactivation time) was determined graphically.

\section{RESULTS AND DISCUSSION}

Malate dehydrogenase mobilities were determined by cooled electrophoresis, which gave lower mobilities than those reported earlier (Shah et al., 1976). The results for 64 strains of pigmented bacteroides (Table 2) confirm that strains now called Bacteroides gingivalis (Coykendall et al., 1980) and previously recognized as the low percentage $G+C$ group of $B$. melaninogenicus subspecies asaccharolyticus (Shah et al., 1976), have a lower MDH mobility than most strains of Bacteroides asaccharolyticus (Finegold \& Barnes, 1977), which was previously recognized as the high $\mathrm{G}+\mathrm{C}$ group of $B$. melaninogenicus subspecies asaccharolyticus (Shah et 
Table 2. Mobilities of malate dehydrogenase in strains of pigmented Bacteroides

Strain Relative mobility* (cm)

\begin{tabular}{|c|c|}
\hline \multicolumn{2}{|l|}{ Bacteroides gingivalis } \\
\hline P157, P210 & $2 \cdot 7$ \\
\hline WPH15, WPH35 & $2 \cdot 8$ \\
\hline WPH34 & $2 \cdot 9$ \\
\hline W50, W83 & $3 \cdot 1$ \\
\hline \multicolumn{2}{|l|}{ Bacteroides asaccharolyticus } \\
\hline VPI 4198 & $3 \cdot 2$ \\
\hline B536, B537, NCTC 9337 & $4 \cdot 3$ \\
\hline B477, VPI 4199 & $4 \cdot 4$ \\
\hline \multicolumn{2}{|l|}{$\begin{array}{l}\text { Bacteroides melaninogenicus } \\
\text { subsp. intermedius }\end{array}$} \\
\hline T588, T584, M107, NCTC 9336, S3, NCTC 9338 & $4 \cdot 0$ \\
\hline P209, P156 & $4 \cdot 1$ \\
\hline B9, B18, 2845, 2846, LH107, AM1726 & $4 \cdot 2$ \\
\hline S9, S20, S23, S24, S12, N275-70A, S1, S4 & $4 \cdot 3$ \\
\hline 2849 & $4 \cdot 5$ \\
\hline B22, B23, JP1, LH45, LH100, 3b, D13a-f1 & $4 \cdot 6$ \\
\hline G11a-d2, LH116 & $4 \cdot 7$ \\
\hline \multicolumn{2}{|l|}{$\begin{array}{l}\text { Bacteroides melaninogenicus } \\
\text { subsp. melaninogenicus }\end{array}$} \\
\hline VPI 9085 & $3 \cdot 2$ \\
\hline VPI 4196 & $5 \cdot 1$ \\
\hline WAL2728, WAL2721, WAL2724, 23K9, S14 & $5 \cdot 2$ \\
\hline WAL $3150, \mathrm{~S} 25, \mathrm{~S} 21, \mathrm{~S} 22$ & $5 \cdot 3$ \\
\hline N138-71, N334-71H & $5 \cdot 4$ \\
\hline $\mathrm{S} 2$ & $5 \cdot 8$ \\
\hline S5 & $5 \cdot 9$ \\
\hline S13 & $6 \cdot 0$ \\
\hline S26 & $6 \cdot 1$ \\
\hline $\mathrm{S} 18$ & $6 \cdot 2$ \\
\hline \multicolumn{2}{|l|}{$\begin{array}{l}\text { Bacteroides melaninogenicus } \\
\text { subsp. levii }\end{array}$} \\
\hline JP2 & $2 \cdot 7$ \\
\hline Lev 1 & $3 \cdot 9$ \\
\hline
\end{tabular}

* All MDH mobilities were measured relative to the enzyme of strain T588.

al., 1976). The large group of 31 strains of $B$. melaninogenicus subspecies intermedius show a continuous spectrum of migration distances. This range is shown as a broad band in Fig. 1 . The electrophoresis of this enzyme does not distinguish these strains from those of $B$. asaccharolyticus. Amongst 18 strains of $B$. melaninogenicus subspecies melaninogenicus, MDH showed two mobility clusters, the larger $5 \cdot 1-5 \cdot 4 \mathrm{~cm}$, and the smaller $5 \cdot 8-6 \cdot 2 \mathrm{~cm}$. One strain (VPI 9085) has an abnormally low enzyme migration of $3.2 \mathrm{~cm}$ and high DNA base composition (Shah et al., 1976) which indicates that it cannot be a member of this taxon despite its physiological properties. Like B. asaccharolyticus, the two strains of $B$. melaninogenicus subspecies levii have similar DNA base compositions (van Steenbergen et al., 1979) and a high DNA-DNA homology with each other (van Steenbergen \& de Graaff, 1979), but different malate dehydrogenase mobilities. Despite heterogeneity within them, the subspecies intermedius, levii and melaninogenicus are all sufficiently different to warrant elevation to species rank (Williams \& Shah, 1980).

Five strains received, or initially diagnosed, as $B$, oralis had three patterns of MDH and GDH mobility. B. oralis ATCC 33269, the neotype strain (Skerman et al., 1980), is the only authentic strain of this species examined. The two strains now called Bacteroides buccalis and the two called Bacteroides denticola (Shah \& Collins, 1981) resemble ATCC 33269 physiologically, but 


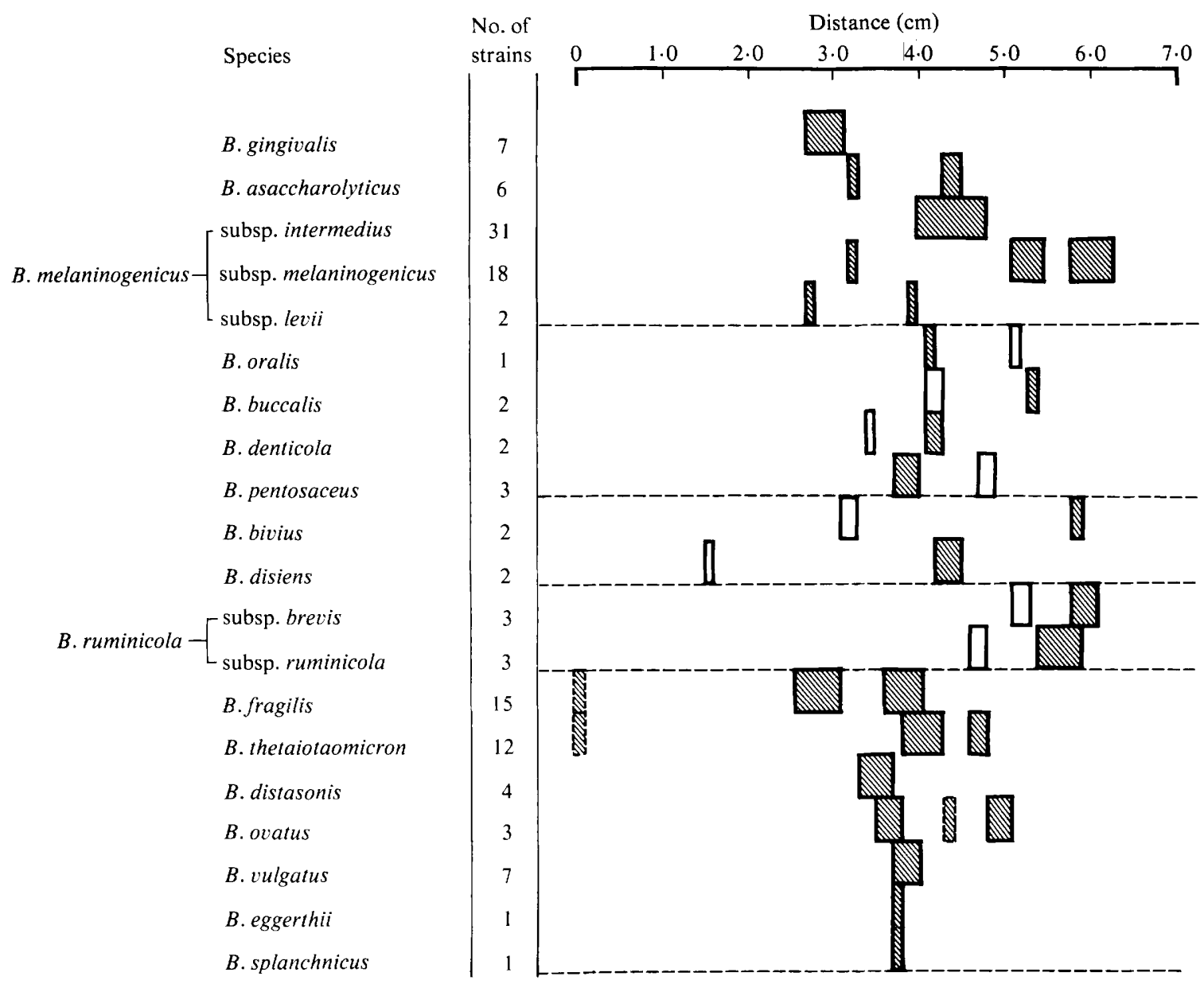

Fig. 1. Electrophoretic patterns of malate dehydrogenase (hatched, faint bands with broken outlines) and glutamate dehydrogenase (unhatched bands) amongst bacteroides strains.

differ in their enzyme patterns (Table 3 and Fig. 1), lipid composition (Shah \& Collins, 1980), DNA base composition and DNA homology (Shah et al., 1981). Two strains which were received as $B$. oralis (5540 and 7880 ) show identical MDH and GDH mobilities to reference strains of Bacteroides bivius (Table 3). Similar DNA base composition and high DNA homology amongst these four strains confirm this relationship (Shah et al., 1981). Bacteroides disiens phenotypically resembles B. bivius except in the fermentation of lactose and galactose. DNA homology (Holdeman \& Johnson, 1977) distinguishes these two species, however the combined use of MDH and GDH electrophoresis (Table 3 and Fig. 1) provides a simple and reliable method of identifying such strains.

Strains of oral origin which were considered to be $B$. oralis, but which ferment pentoses and contain $50 \% \mathrm{G}+\mathrm{C}$ were described as $B$. ruminicola subspecies brevis (personal communication L. V. Holdeman). These three strains (NP 333, WPH 61 and J1, Table 3) have enzyme mobilities which are quite distinct from those of reference strains of either subspecies of $B$. ruminicola (Fig. 1), and they have been allocated to Bacteroides pentosaceus (Shah \& Collins, 1981) on other chemotaxonomic criteria.

The stimulation of growth by bile (Holdeman et al., 1977) or sodium taurocholate (Duerden et 
Table 3. Mobilities of malate dehydrogenase and glutamate dehydrogenase in putative strains of Bacteroides oralis, Bacteroides ruminicola, Bacteroides bivius and Bacteroides disiens

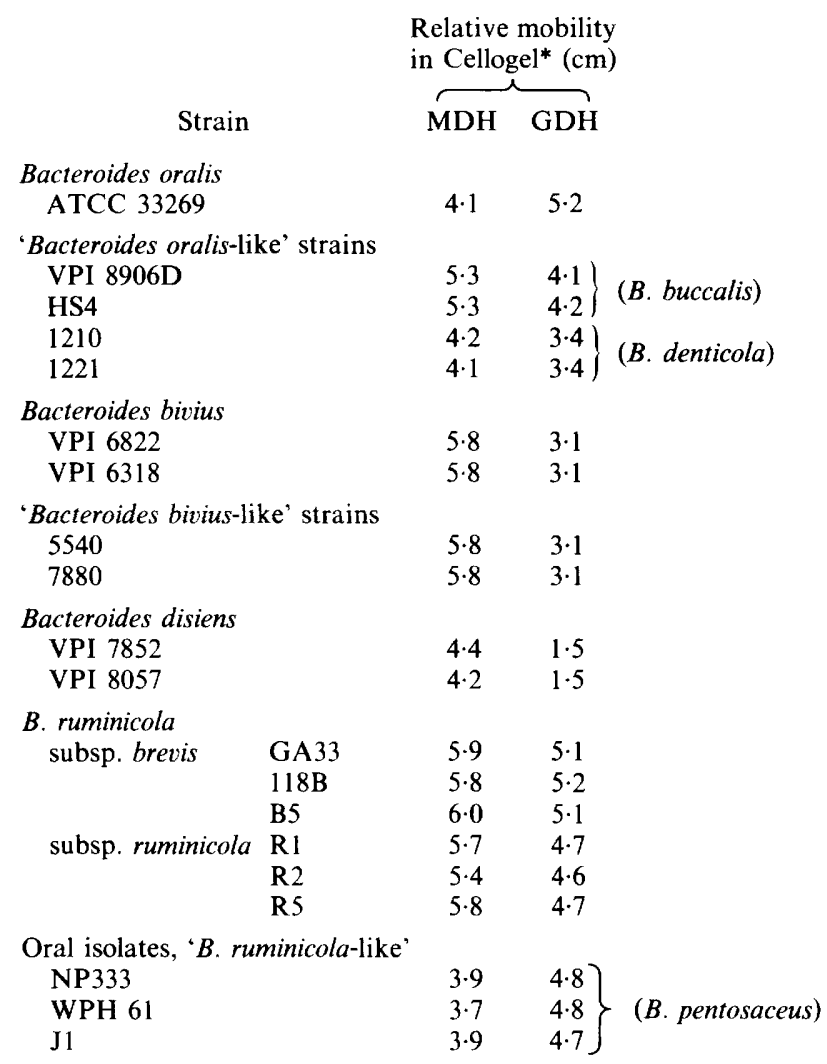

* All MDH mobilities were measured relative to the enzyme of strain T588.

$a l .$, 1976) is a unique property of the ' $B$. fragilis group of species'. Forty-three strains (nine reference and thirty-four recent clinical isolates) which belong to this group have been examined enzymologically. Fifteen strains of $B$. fragilis, twelve of Bacteroides thetaiotaomicron and three of Bacteroides ovatus all had species-specific patterns of MDH that comprised three bands (Fig. 1). Bacteroides distasonis, Bacteroides vulgatus, Bacteroides eggerthii and Bacteroides splanchnicus strains all had single MDH bands of such similar mobility as to render them indistinguishable. Amongst these four species the electrophoresis of GDH produced similar fast migrating bands in B. distasonis and B. vulgatus, while B. eggerthii and B. splanchnicus enzyme moved less than half this distance (Table 4). Enzyme assay of all 43 strains revealed the presence of glucose-6phosphate dehydrogenase and 6-phosphogluconate dehydrogenase (Table 4) enzymes that were universally absent in all other bacteroides species tested. It seems, therefore, that the presence of these two enzymes of the pentose phosphate pathway are diagnostic of species of the ' $B$. fragilis group'. The magnitude of the specific enzyme activity of all four dehydrogenases (Table 4) is not significantly different between these species. It was not possible to identify a strain as belonging to a species using the mobility of either G6PDH or 6PDGH because of ambiguities, e.g. both $B$. eggerthii and $B$. splanchnicus have G6PDH of the same migration rate. However, taken together the electrophoresis of both enzymes provided unambiguous identification (Table 4). Thirty fresh clinical isolates were identified by these species-specific electrophoretic patterns before the 


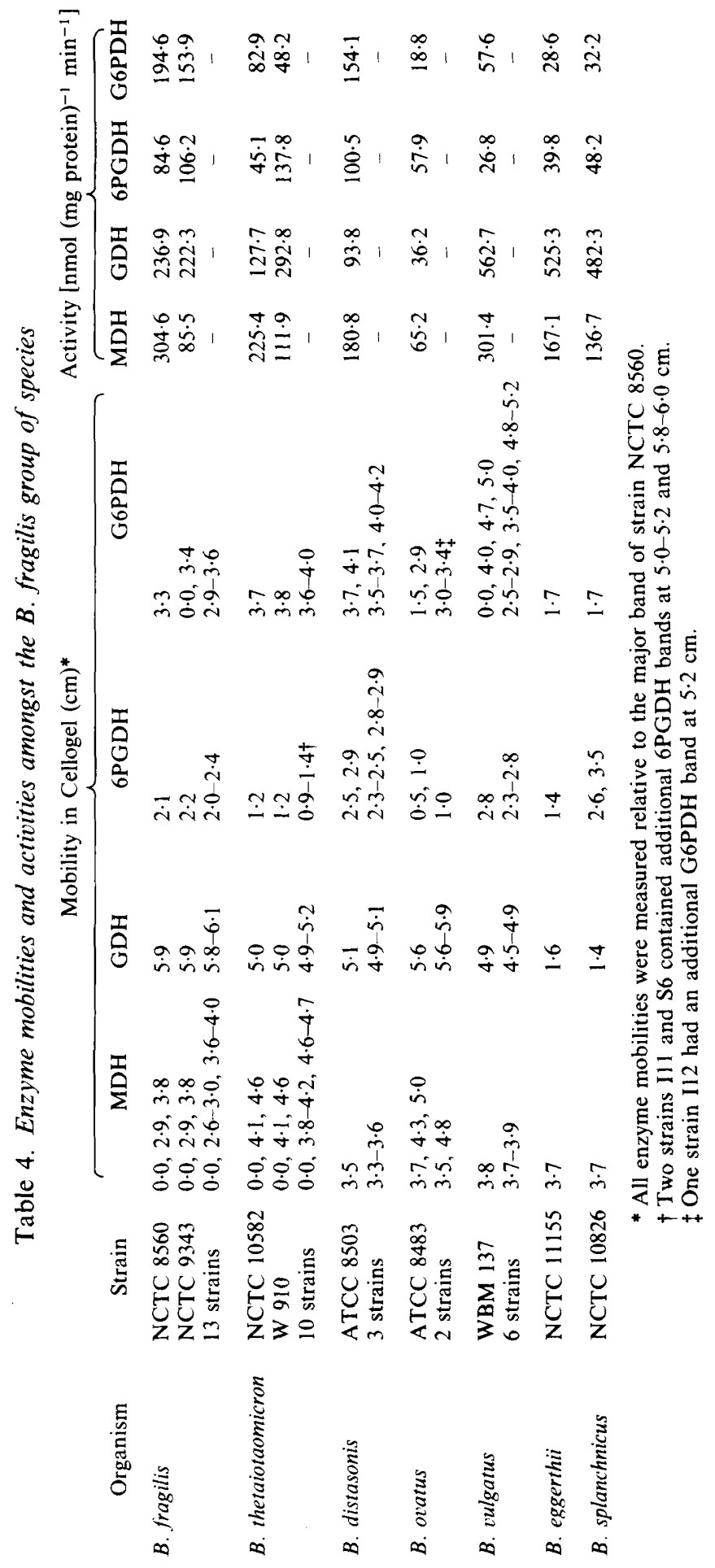


Table 5. Time of half inactivation of malate dehydrogenase of pigmented Bacteroides in alkaline buffers at $37^{\circ} \mathrm{C}$

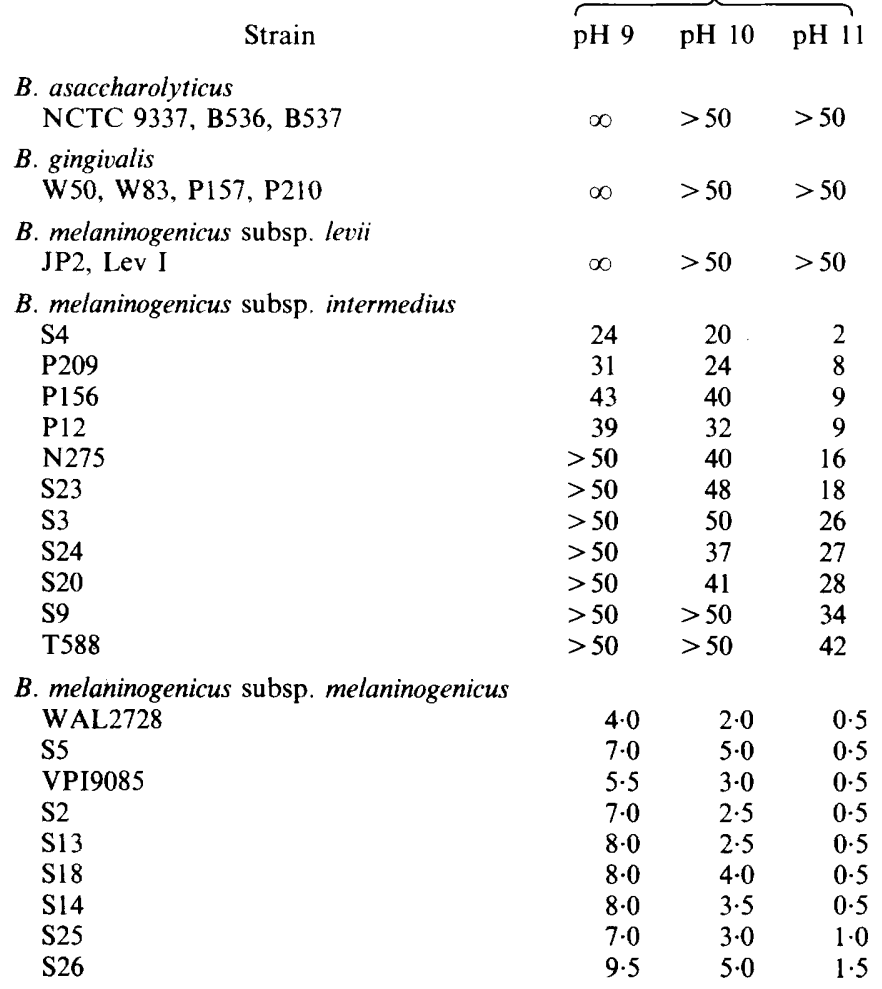

* $\infty$ indicates no loss of enzyme activity was detected in $50 \mathrm{~min}$ and $>50$ indicates the loss of activity was linear but the extent was so small as to render the estimation of $t_{0.5}$ inaccurate.

clinical laboratory had examined them. In every case the identification by electrophoresis was confirmed by more conventional tests (Holdeman et al., 1977).

The $\mathrm{pH}$ optimum for the reduction of oxaloacetate by malate dehydrogenase in cell-free extracts of bacteroides was found to be $\mathrm{pH} 8.4$ for B. gingivalis strain W 83 and B. melaninogenicus subspecies intermedius strain $\mathrm{T} 588$, but $\mathrm{pH} 7.5$ for $B$. melaninogenicus subspecies melaninogenicus strain WAL 2728. Such examinations were of limited taxonomic importance; however, the stability of $\mathrm{MDH}$ at $\mathrm{pH} \mathrm{9,10}$ and 11 (Table 5 and Fig. 2) was of greater significance. This enzyme from $B$. asaccharolyticus, $B$. gingivalis and $B$. melaninogenicus subsp. levii was highly stable in these alkaline buffers. Strains of $B$. melaninogenicus subspecies intermedius contained $\mathrm{MDH}$ that was less stable at $\mathrm{pH} 10$ and 11 , and using the latter $\mathrm{pH}$ the half life of the enzyme lay between 2 and $42 \mathrm{~min}$. With $\mathrm{pH} 11, \boldsymbol{B}$. melaninogenicus subspecies intermedius strains were readily distinguished from those of the asaccharolytic species. The malate dehydrogenase of $B$. melaninogenicus subspecies melaninogenicus was the least stable of all. Any of the three $\mathrm{pH}$ values used could distinguish a strain of this subspecies (Table 5) although inactivation at $\mathrm{pH} 11$ was so rapid as to make the determination of half-life inaccurate. This test may be carried out on cells harvested from a single blood agar plate and can be completed within $2 \mathrm{~h}$, and several strains may be examined in parallel. Susceptibility to alkaline denaturation parallels the metabolic properties in that saccharolytic potential is associated with instability of malate dehydrogenase, whereas asaccharolytic bacteroides have stable enzymes. 


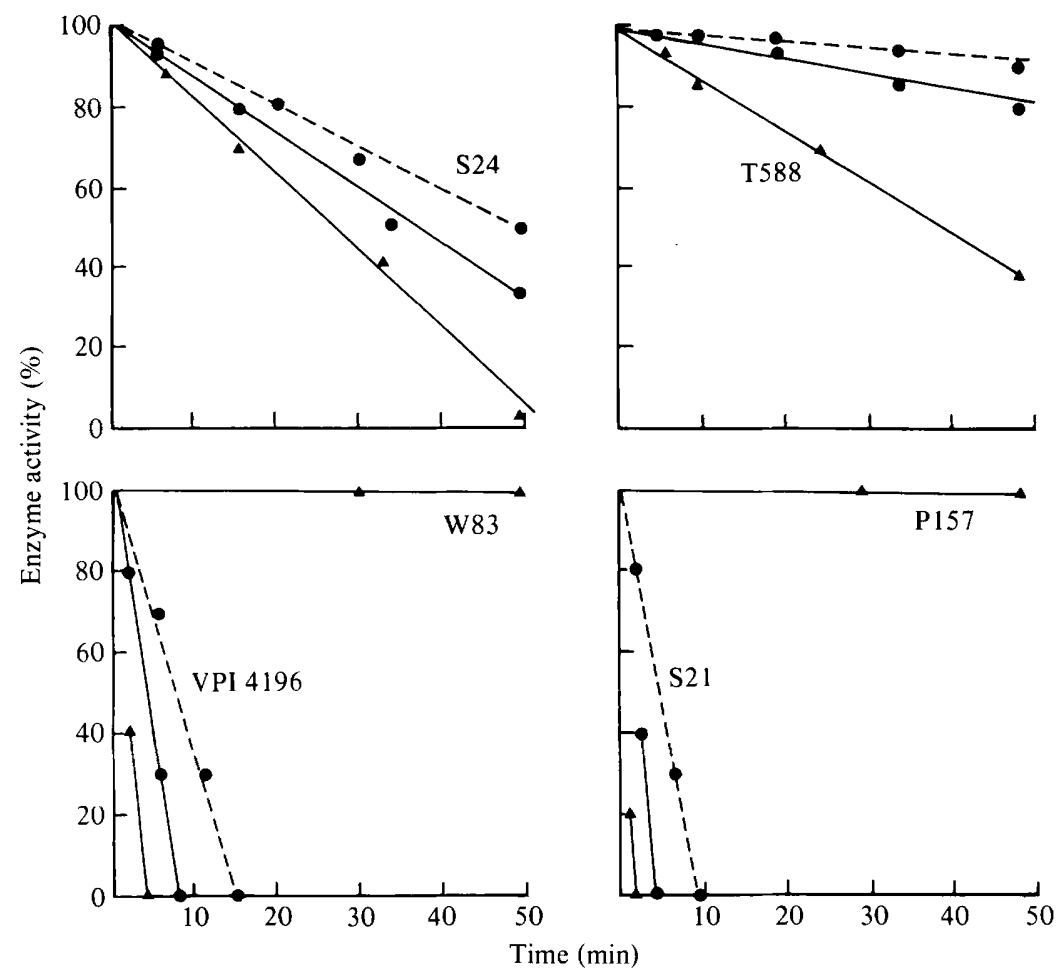

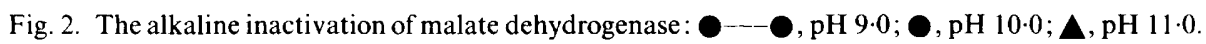
Upper graphs: Bacteroides melaninogenicus subsp. intermedius strains T588 and S24. Lower graphs: neglible inactivation of Bacteroides gingivalis enzyme of strains W83 and P157 at pH 11 and rapid inactivation of enzyme of Bacteroides melaninogenicus subsp. melaninogenicus strains VPI 4196 and S21. The subspecies of the $\mathrm{S}$ strains were first identified by the stability of MDH to alkali, and subsequently confirmed.

\section{REFERENCES}

BASCOMBE, S. (1980). Identification of bacteria by measurement of enzyme activities and its relevance to the clinical diagnostic laboratory. In Microbiological Classification and Identification, pp. 359 373. Edited by M. Goodfellow \& R. G. Board. London: Academic Press.

Coykendall, A. L., Kaczmarek, F. S. \& Slots, J. (1980). Genetic heterogeneity in Bacteroides asaccharolyticus (Holdeman and Moore 1970) Finegold and Barnes 1977 (Approved Lists, 1980) and proposal of Bacteroides gingivalis $\mathrm{sp}$. nov. and Bacteroides macacae (Slots and Genco) comb. nov. International Journal of Systematic Bacteriology 30, $559-564$

DE LEY, J. (1962). Comparative biochemistry and enzymology in bacterial classification. In Microbial Classification, pp. 164-195. Edited by G. C. Ainsworth \& P. H. A. Sneath. Cambridge: Cambridge University Press.

DE LEY, J. (1968). Molecular biology and bacterial phylogeny. In Evolutionary Biology, vol. 2, pp. 103156. Edited by T. Bodzhansky, H. K. Hecht \& W. C. Steere. Amsterdam: North Holland.

Duerden, B. I., Holbrook, W. P. \& Collee, J. G. (1976). The characterization of clinically important gram-negative anaerobic bacilli by conventional bacteriological tests. Journal of Applied Bacteriology 40, $163-188$

Finegold, S. M. \& Barnes, E. M. (1979). Report of the ICSB Taxonomic Subcommittee on Gram-negative anaerobic rods. Proposal that the saccharolytic and asaccharolytic strains at present classified in the species Bacteroides melaninogenicus (Oliver and Wherry) be reclassified in two species as Bacteroides melaninogenicus and Bacteroides asaccharolyticus. International Journal of Systematic Bacteriology 27, 388-391.

Holdeman, L. V. \& Johnson, J. L. (1977). Bacteroides disiens sp. nov. and Bacteroides bivius sp. nov. from human clinical infections. International Journal of Systematic Bacteriology 27, 337-345.

Holdeman, L. V., Cato, E. P. \& Moore, W. E. C. (1977). Anaerobe Laboratory Manual, 4th edn. Blacksburg, Virginia, U.S.A.: V.P.I. Anaerobe Laboratory.

NoRRIS, J. R. (1968). The application of gel electrophoresis to the classification of micro-organisms. In Chemotaxonomy and Serotaxonomy, pp. 49-56. Edited by J. G. Hawkes. London: Academic Press.

Reeves, H. C., Rabin, R., Wegener, W. S. \& AJl, S. J. (1971). Assays of enzymes of the tricarboxylic acid 
and glyoxylate cycles. Methods in Microbiology 6A, $425-462$.

SHAH, H. N. (1981). Biochemical properties of Bacteroides melaninogenicus and related taxa. Ph.D. thesis, University of London.

ShaH, H. N. \& Collins, M. D. (1980). Fatty acid and isoprenoid quinone composition in the classification of Bacteroides melaninogenicus and related taxa. Journal of Applied Bacteriology 48, 75-87.

SHAH, H. N. \& Collins, M. D. (1981). Bacteroides buccalis sp. nov., Bacteroides denticola sp. nov. and Bacteroides pentosaceus. New Species of the genus Bacteroides from the oral cavity. Zentralbatt für Bakteriologie, C 2, 235-241.

Shah, H. N., Williams, R. A. D., Bowden, G. H. \& HARDIE, J. M. (1976). Comparison of the biochemical properties of Bacteroides melaninogenicus from human dental plaque and other sites. Journal of Applied Bacteriology 41, 473-492.

Shah, H. N., van Steenbergen, T. J. M., Hardie, J. M. \& DE GRAAFF, J. (1981). DNA base composition, DNA-DNA reassociation and isoelectric focusing of proteins of strains designated Bacteroides oralis. FEMS Microbiology Letters 13, 125-130.

SHAw, C. R. (1965). Electrophoretic variation in enzymes. Science 149, 936-942.

Skerman, V. B. D., McGowan, V. \& SNeath, P. H. A. (1980). Approved lists of bacterial names. International Journal of Systematic Bacteriology 30, 225420.

SOKATCH, J. R. (1969). Fermentation of sugars. In Bacterial Physiology and Metabolism, pp. 72-111. Edited by J. R. Sokatch. New York: Academic Press. van Steenbergen, T. J. M. \& de Graaff, J. (1979). Genetic relationship between different subspecies of Bacteroides melaninogenicus. Journal of Dental Research 59, 1823.

van Steenbergen, T. J. M., De Soet, J. J. \& DE GRAAFF, J. (1979). DNA base composition of various strains of Bacteroides melaninogenicus. FEMS Microbiology Letters 5, 127-130.

van Steenbergen, T. J. M., Vlaanderen, C. A. \& De GraAFF. J. (1981). Confirmation of Bacteroides gingivalis as a species distinct from Bacteroides asaccharolyticus. International Journal of Systematic Bacteriology 31, 236-241.

WeitzMan, P. D. J. (1980). Citrate synthase and succinate thiokinase in classification and identification. In Microbiological Classification and Identification, pp. 107-125. Edited by M. Goodfellow \& R. G. Board. London: Academic Press.

Williams, R. A. D. \& Bowden, E. (1968). The starch gel electrophoresis of glucose-6-phosphate dehydrogenase and glyceraldehyde-3-phosphate dehydrogenase of Streptococcus faecalis, $S$. faecium and S. durans. Journal of General Microbiology 50, 329-336.

Williams, R. A. D., Bowden, G. H., Hardie, J. M. \& SHAH, H. (1975). Biochemical properties of Bacteroides melaninogenicus subspecies. International Journal of Systematic Bacteriology 25, 298-300.

Williams, R. A. D. \& Shah, H. N. (1980). Enzyme patterns in bacterial classification and identification. In Microbiological Classification and Identification, pp. 299-315. Edited by M. Goodfellow \& R. G. Board. London: Academic Press. 